\title{
The California Rangeland Conservation Coalition
}

\section{Grazing research supports an alliance for working landscapes.}

\section{By Sheilla Barry, Tracy K. Schohr, and Karen Sweet}

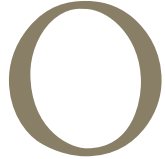
ne thing this issue of Rangelands has made clear is that conserving working landscapes often means working across property lines and in collaboration with planners, agencies, conservation groups, landowners, and the ranching industry. A ranch in the San Francisco Bay Area was the backdrop for a meeting between environmentalists, ranchers, and resource professionals from federal and state agencies. From this meeting of former foes in the Summer of 2005, participants drafted

\section{Table 1. California native plants and animals} which benefit from managed grazing

\begin{tabular}{|l|l|}
\hline Common & Scientific \\
\hline $\begin{array}{l}\text { Bay checkerspot } \\
\text { butterfly }\end{array}$ & Euphydryas editha bayensis \\
\hline $\begin{array}{l}\text { California tiger sala- } \\
\text { mander }\end{array}$ & Ambystoma californiense \\
\hline $\begin{array}{l}\text { California red-legged } \\
\text { frog }\end{array}$ & Rana aurora draytonii \\
\hline $\begin{array}{l}\text { Blunt-nosed leopard } \\
\text { lizard }\end{array}$ & Gambelia sila \\
\hline Giant kangaroo rat & Dipodomys ingens \\
\hline $\begin{array}{l}\text { San Joaquin kangaroo } \\
\text { rat }\end{array}$ & Dipodomys nitratoides \\
\hline $\begin{array}{l}\text { San Joaquin antelope } \\
\text { squirrel }\end{array}$ & Ammospermophilus nelsoni \\
\hline Santa Cruz tarplant & Holocarpha macradenia \\
\hline
\end{tabular}

a resolution documenting common ground for the conservation of the rangeland encircling the central valley, including the Sierra foothills and interior coast ranges. The resolution recognized that these wildlife-rich rangelands have been shaped by grazing and the other land stewardship practices of the ranchers who own and manage them. Recent research contributed to this alliance, by showing how well-managed grazing can provide improved habitat values.

The resolution is currently signed by 64 agricultural organizations, environmental interest groups, as well as state and federal agencies (see The California Rangeland Resolution). Together these signatories form the California Rangeland Conservation Coalition. The signatories have pledged to work together to preserve and enhance California's rangeland for species of special concern, while supporting the long-term viability of the ranching industry. An important part of the group's effort will focus on educating the public about the benefits of grazing and ranching on these rangelands.

The value of grazing and other land stewardship practices of California's ranchers is being increasingly acknowledged not only as a preferred land use but also as an essential resource management tool. Reduction of fire hazard is widely considered a reason to graze by private and public landowners, because grazing reduces fine fuels and suppresses shrub invasion on many fire-prone California rangelands. However, published rangeland research has now also documented the other positive benefits of grazing on the habitat of several special status species.

This article has been peer reviewed. 


\section{The California Rangeland Resolution}

The undersigned recognize the critical importance of California's privately owned rangelands, particularly that significant portion that encircles the Central Valley and includes the adjacent grasslands and oak woodlands, including the Sierra foothills and the interior coast ranges. These lands support important ecosystems and are the foundation for the ranching industry that owns them.

WHEREAS, these rangelands include a rich and varied landscape of grasslands, oak woodlands, vernal pools, riparian areas and wetlands, which support numerous imperiled species, many native plants once common in the Central Valley, and are home to the highest diversity and density of wintering raptors anywhere in North America;

WHEREAS, these rangelands are often located in California's fastest-growing counties and are at significant risk of conversion to development and other uses;

WHEREAS, these rangelands, and the species that rely on these habitats, largely persist today dne to the positive and experienced grazing and other land stewardship practices of the ranchers that have owned and managed these lands and are committed to a healthy future for their working landscapes;

WHEREAS, these rangelands are a critical foundation of the economic and social fabric of California's ranching industry and rural communities, and will only continue to provide this important working landscape for California's plants, fish and wildlife if private rangelands remain in ranching;

THEREFORE, we declare that it is our goal to collaboratively work together to protect and enhance the rangeland landscape that encircles California's Central Valley and includes adjacent grasslands and oak woodlands by:

- Keeping common species common on private working landscapes;

- Working to recover imperiled species and enhancing habitat on rangelands while seeking to minimize regulations on private lands and streamline processes;

- Supporting the long-term viability of the ranching industry and its culture by providing economic, social and other incentives and by reducing burdens to proactive stewardship on private ranchlands;

- Increasing private, state and federal funding, technical expertise and other assistance to contimue and expand the ranching community's beneficial land stewardship practices that benefit sensitive species and are fully compatible with normal ranching practices;

- Encouraging voluntary, collaborative and locally-led conservation that has proven to be very effective in maintaining and enitancing working landscapes;

- Educating the public about the benefits of grazing and ranching in these rangelands.

\section{SIGNED BY:}

A lameda County Board of Supervisors

Alameda Co. Resource Conservation District

Amador Resource Conservation District

American Farmland Trust

American Land Conservancy

Audub on California

Bureau of Land Management

Butte Environmental Counci

Butte County Resource Conservation District

Calaveras Co. Resource Conservation District

California $\Lambda$ ssociation of Resource Conservation

Districts

California Cattlemen's Association

California CattleWornern's Association

California Chapter of the International Soil and

Water Conservation Society

California Department of Conservation

California Dept of Fish and Game
California Dept of Food and Agriculture California Dept of Forestry and Fire Protection

California Farm Bureau Federation

California Grazing Lands Coalition

California Invasive Plant Council

California Nativc Grasslands Association

California Native Plant Society

Califorria Oak Foundation

California Rangeland Trust

California Resources Agency

California Wildlife Foundation

California Wool Growers Association

Cal-Pac Section Society of Range Management

Ceritral Sierra Region of Resource Conservation

Districts

Central Valley Land Trust Council

City of Livermore

Defenders of Wildlife
Ducks Unlimited

El Dorado Resource Conservation District

Environmental Defense

Glenn County Resource Conservation District

Institute for Ecological Health

Jumping Frog Rescarch Institutc

Mariposa Co. Resource Conservation Distric

National Wild Turkey Federation

National Cattlemen's Beef Association

Natural Resources Conservation Service

Nevada Co. Resource Conservation District

Nevada County Land Trust

Northern California Regional Land Trust

Placer Co. Resource Conservation District

Sacramento River Watershed Program

San Joaquin Raptor/Wildlife Rescue Center

San Joaquin Valley Conservancy

Sicrra Foothills Audub on Socicty
State Water Resources Control

Board

Sustainable Conservation

Tehama Country Resource

Conservation District

The Nature Conscrvancy

Trust for Public Land

Tuolumne Co. Resource

Conservation District

University of California

US Fish and Wildlife Service

US Forcst Scrvicc

VernalPools org

Western Shasta Resource

Conservation District

Wildlife Conservation Board

WildPlaces

March 6, 2007
In California's southern San Joaquin Valley, wildlife biologist Dr David Germano and team found that cover of nonnative grasses and forbs often creates an impenetrable thicket for small, ground-dwelling vertebrates. Many of the small vertebrates that evolved in this habitat of saltbrush scrub rely on open ground to forage and avoid predation. Preliminary

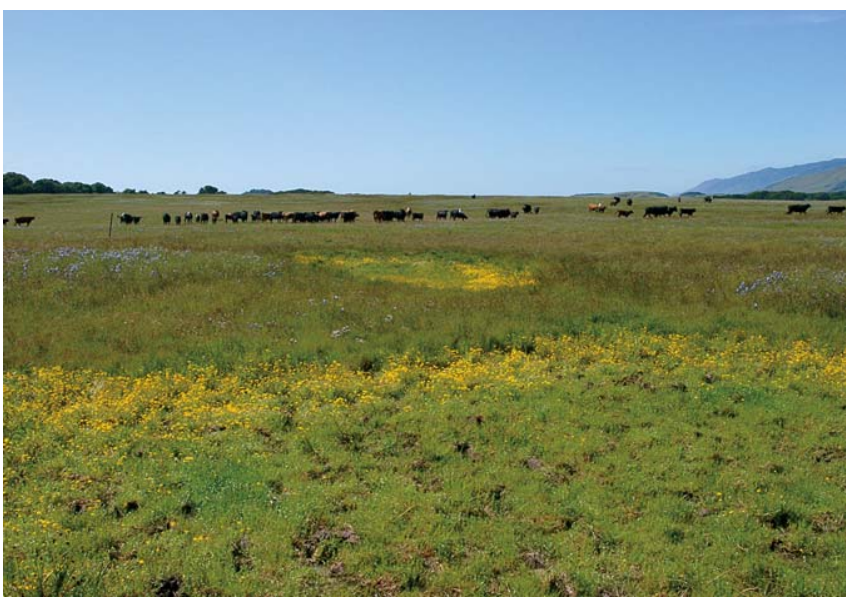

Grazed vernal pool habitat on the Hearst Ranch. Photo by Sheila Barry. research indicates that populations of giant kangaroo rats, San Joaquin kangaroo rats, San Joaquin antelope squirrels, and blunt-nosed leopard lizards, all listed as threatened or endangered, are affected negatively by thick ground cover. The researchers acknowledge that although grazing might originally have contributed to the introduction of nonnative plants, moderate to heavy grazing by livestock at the present time might be the best way to ameliorate the habitat for these small vertebrates. ${ }^{1}$

In the California's Central Valley, Dr Jaymee Marty, an ecologist with The Nature Conservancy, found that grazing maintained native plant and invertebrate diversity in ephemeral wetlands or vernal pools. She found that invasion by nonnative annual species reduced native plant cover and wetland inundation periods. Her study across 72 vernal pools examined the effect of different grazing treatments (ungrazed, continuously grazed, wet-season grazed, and dry-season grazed) on vernal-pool plant and aquatic faunal diversity. After 3 years of treatment, she found that ungrazed pools had $47 \%$ lower relative cover of native species and $88 \%$ higher cover of nonnative annual grasses than pools grazed at historical levels (continuously grazed). Species richness of native plants also declined 


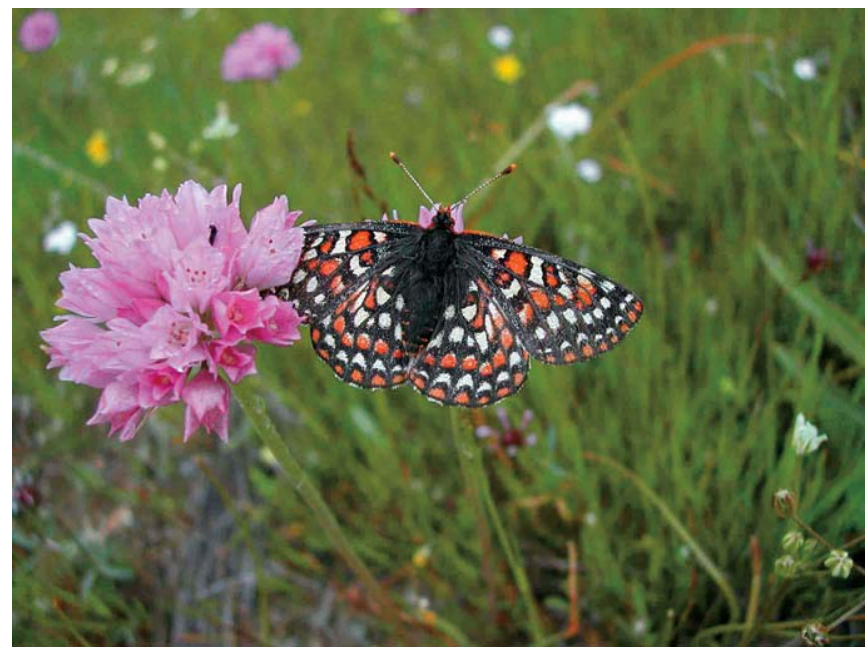

Bay checkerspot butterfly. Photo by Stuart Weiss.

by $25 \%$ and aquatic invertebrate diversity was $28 \%$ lower in the ungrazed compared with the continuously grazed treatments. The inundation period of the pools was reduced by $50 \%$ to $80 \%$ in ungrazed pools, making it difficult for some vernal-pool endemic species to complete their life cycle. ${ }^{2}$

Similar impacts from nonnative annual species have been found on serpentine sites south of San Francisco Bay. These serpentine sites support many rare species, including the endangered Bay checkerspot butterfly. Conservation biologist Dr Stuart Weiss surveyed butterfly and plant populations across different grazing regimes. He observed that several populations of the butterfly in south San Jose were extirpated following the exclusion of cattle grazing, whereas nearby populations under continued grazing did not decline. His research determined that Nitrogen $(\mathrm{N})$ deposition from automobile emissions is threatening biodiversity in these grasslands because $\mathrm{N}$ is the primary limiting nutrient for plant growth on serpentine soils. Fertilization experiments have shown that soil $\mathrm{N}$ limits grass invasion in serpentine soils. Estimated $\mathrm{N}$ deposition rates in south San Jose grasslands are 10-15 $\mathrm{kg} \mathrm{N} \cdot \mathrm{ha} \cdot$ year. Dr Weiss noted that grazing cattle select grasses over forbs and grazing leads to a net export of $\mathrm{N}^{3}$

Benefits of grazing have also been documented on California's coastal grasslands. Plant ecologist Dr Grey Hayes examined the declining trends in annual wildflowers such as the endangered Santa Cruz tarplant. He noted that the 2 primary threats to California's coastal prairies are human development and invasion by exotic weeds, but a third major threat is the cessation of grazing. He carefully documented the changes in one population of tarplant that flourished in harmony with cattle grazing, disappeared after grazing was removed, and reappeared years later after extreme human intervention. ${ }^{4}$

In another study, Hayes et $\mathrm{al}^{5}$ investigated the impact of cattle grazing on the California coastal prairie plant community. He surveyed 25 paired grazed and ungrazed sites for vegetation community composition, vegetation structure, and soil chemical parameters. The surveys were conducted for 2

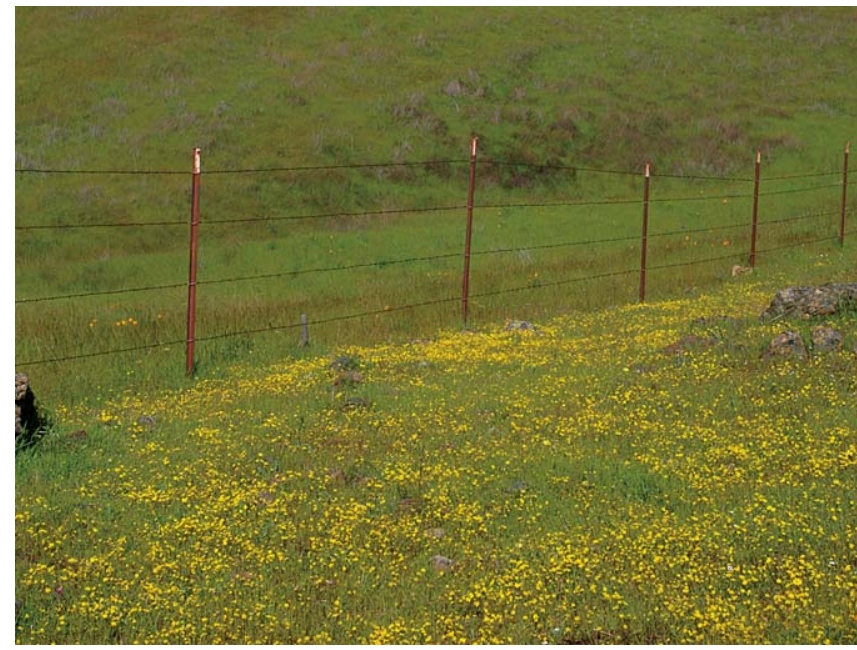

Butterfly fenceline: the land on the side of the fence covered with goldfields is grazed by cattle. The land on the other side of the fence has been rested for a number of years and no longer supports the Bay checkerspot butterflies. Photo by Sheila Barry.

years during the spring on sites across a 425 -mile range of the ecosystem. Native annual forb species richness and cover were higher in grazed sites, and this effect coincided with decreased vegetation height and litter depth. Soil properties explained less of the variation. Exotic annual grass and forb cover were also higher in grazed sites. Native grass cover and species richness did not differ in grazed and ungrazed sites, but cover and species richness of native perennial forbs was higher on ungrazed sites. Based on these results, Hayes et al recognized that cattle grazing might be a valuable management tool to conserve native annual forbs, many of which are species of concern.

Because it is supported by scientific research, the message that grazing can benefit habitat on California's rangelands has been heard beyond the conservation research community and is impacting conservation regulations. The federal listing of 2 species within California contain the $4 \mathrm{~d}$ rule. ${ }^{6,7}$ The rule exempts routine ranching practices from the prohibitions of the Endangered Species Act (ESA), including taking, harming and harassing listed species. The US Fish and Wildlife Service has recognized that ranching activities, including grazing and maintenance of stockponds, benefit the California red-legged frog and the California tiger salamander. The US Fish and Wildlife Service took the lead in bringing together ranchers, environmentalists, and regulators to draft the California Rangeland Resolution and establish the California Rangeland Conservation Coalition.

Coalition members first gathered on January 11, 2006. The day-long summit drew over 80 members. A list of the coalition's goals was defined and prioritized throughout the day and became an action plan. The plan, the CA Rangeland Conservation Resolution, laid the foundation for coalition members to work together to acquire additional federal funding for conservation programs, coordinate permitting processes, garner support for cooperative conservation projects, and provide landowner assurances and incentives for 
proactive voluntary conservation. As a coalition member, the California-Pacific Section of the Society for Range Management will be working with other coalition members to identify and close gaps in our knowledge of grassland and oak woodland management and its benefit to wildlife habitat. Coalition members have joined forces twice in Washington, D.C., March 2006 and March 2007, to present the coalition and advocate its priorities on Capitol Hill.

Scientific research has demonstrated what many have long believed: grazing can be an important component of ecosystem management. It can also help managers evaluate options and improve stewardship. Together with collaborative efforts that cross boundaries and create partnerships with private landowners, rangeland research can help to create the working landscapes of tomorrow.

Authors are Livestock Advisor, UCCE Santa Clara, University of Cooperative Extension Natural Resources, 1553 Berger Drive, Building 1, San Jose, CA 95112, sbarry@ucdavis.edu (Barry); Director of Rangeland Conservation, California Cattlemen's Association, 1221 H St., Sacramento, CA 95814 (Schohr); and Executive Director, Alameda County Resource Conservation District, 3585 Greenville Road, Suite 2, Livermore, CA 945506710 (Sweet).

\section{References}

1. Germano, D. J., G. B. Rathbun, and L. R. Saslaw. 2001. Managing exotic grasses and conserving declining species. Wildlife Society Bulletin 29(2):551-559.

2. Marty, J. T. 2005. Effects of cattle grazing on diversity in ephemeral wetlands. Conservation Biology 19:1626-1632.

3. Weiss, S. 1999. Cars, cows, and checkerspot butterflies: nitrogen deposition and management of nutrient-poor grasslands for a threatened species. Conservation Biology 13:(6)1476-1486.

4. Hayes, G. 1998. The saga of the Santa Cruz tarplant. Four Seasons 10(4):18-21.

5. Hayes, G. F., And K.D. Holl. 2003. Cattle grazing impacts on annual forbs and vegetation composition of mesic grasslands in California. Conservation Biology 17(6):1694-1702.

6. United States Fish and Wildlife Service. 2004. Endangered and threatened wildlife and plants: Determination of threatened status for the California tiger salamander, and Special rule exemption for existing routine ranching activities. Federal Register 69(149):47212-47248.

7. United States Fish and Wildlife Service. 2005. Endangered and threatened wildlife and plants: Revised proposed designation of critical habitat for the California red-Legged frog (Rana aurora draytonii). Federal Register 70(212):6690667064. 